\title{
Sustainable intensification in agriculture: the richer shade of green. A review
}

\author{
Paul C. Struik ${ }^{1}$ (D) Thomas W. Kuyper ${ }^{2}$
}

Accepted: 21 July 2017 /Published online: 23 August 2017

(C) The Author(s) 2017. This article is an open access publication

\begin{abstract}
Agricultural intensification is required to feed the growing and increasingly demanding human population. Intensification is associated with increasing use of resources, applied as efficiently as possible, i.e. with a concurrent increase in both resource use and resource use efficiency. Resource use efficiency has agronomic, environmental, economic, social, trans-generational, and global dimensions. Current industrial agriculture privileges economic resource use efficiency over the other dimensions, claiming that that pathway is necessary to feed the world. Current agronomy and the concept of sustainable intensification are contested. Sustainable intensification needs to include clarity about principles and practices for priority setting, an all-inclusive and explicit cost-benefit analysis, and subsequent weighing of trade-offs, based on scientifically acceptable, shared norms, thus making agriculture "green" again. Here, we review different forms of intensification, different principles and concepts underlying them, as well as the norms and values that are needed to guide the search for effective forms of sustainable and ecological intensification. We also address innovations in research and education required to create the necessary knowledge base. We argue that sustainable intensification should be considered as a process of enquiry and analysis for navigating and sorting out the issues and concerns in
\end{abstract}

Paul C. Struik

paul.struik@wur.nl

1 Centre for Crop Systems Analysis, Plant Sciences, Wageningen

University \& Research, PO Box 430,

6700 AK Wageningen, The Netherlands

2 Department of Soil Quality, Environmental Sciences, Wageningen University \& Research, PO Box 47, 6700 AA Wageningen, The Netherlands agronomy. Sustainable intensification is about societal negotiation, institutional innovation, justice, and adaptive management. We also make a plea for at least two alternative framings of sustainable intensification: one referring to the need for "de-intensification" in high-input systems to become more sustainable and one referring to the need to increase inputs and thereby yields where there are currently large yield (and often also efficiency) gaps. Society needs an agriculture that demonstrates resilience under future change, an agronomy that can cope with the diversity of trade-offs across different stakeholders, and a sustainability that is perceived as a dynamic process based on agreed values and shared knowledge, insight, and wisdom.

Keywords Agronomy · Intensification · Resilience · Resource use efficiency · Sustainability · Trait-based agroecology $\cdot$ Values

\section{Contents}

1 Introduction

2 Agricultural intensification contested

3 Making agriculture green again

4 Demonstrating different routes to "green" agriculture

4.1 Defining sustainability

4.2 Agricultural sustainability is a complex problem

4.3 Intensification contested

4.4 Efficiency contested

4.5 Sustainable intensification

4.6 Ecological intensification

5 Redefining agronomy

5.1 How to cope with contested concepts?

5.2 Why sustainability should go green

5.3 The social dimensions of sustainable intensification 
6 Describing the need for a link between agronomy and education in sustainability

6.1 A new agronomy and a new role for agronomists 6.2 Education

7 Conclusion

Acknowledgments

References

\section{Introduction}

The planet Earth is in a state of decline, mainly caused by human activity; consequently, many planetary boundaries have been transgressed (Rockström et al. 2009; Steffen et al. 2015) and vulnerability of agricultural and food systems to disturbance has increased (Beroya-Eitner 2016). Industrial agriculture (or high-external-input agriculture) is one of the most disruptive human activities, causing "a major systemic global dysfunctionality" (Wals 2015). Yet, industrial agriculture is likely to remain a main source of food supply, driven and maintained by the combination of high labor costs and relatively low costs of external inputs (IPES-Food 2016), unless the cost-benefit analysis of agricultural production is made in a different (and better) way, based on full accounting of all costs and proper pricing of scarce goods. Within the current economic paradigm and given that the world's population is increasing, dietary demands per capita are increasing, while at the same time the natural resource base (arable land of good quality, fresh water, nutrients, energy) (IPES-Food 2016; Valenzuela 2016) as well as the human resources (experienced, resourceful, and innovative farmers and agronomists) (Struik et al. 2014) are eroding, it is likely that planetary boundaries will even be further exceeded. Governing bodies, policy makers, non-governmental organizations, citizens but also producers and other actors making use of natural resources worry about this process of decline, and therefore, "sustainability" is a frequently used noun and "sustainable" a frequently used attributive adjective, especially in relation to agriculture. The general opinion implied in the expression "sustainable agriculture" is that continuation of the conventional way of industrial agriculture (business-as-usual) is no longer possible (Van Noordwijk and Brussaard 2014; Mahon et al. 2017).

In subsistence agriculture, the situation is different, but equally worrying. The common trends in that type of agriculture are that soil fertility is in decline (Tittonell and Giller 2013) and that labor availability is increasingly scarce because of migration of farm household members to cities for wage labor (Qin 2010; Satterthwaite et al. 2010).

It is a moral imperative to ensure that enough food of adequate quality is produced for humankind, that all humans have access to the food of their preference in a fair manner, that production is taking place without eroding the natural resource base, and that access to natural resources is fairly distributed over the current world population and guaranteed for future generations. Fraser et al. (2016) identified four perspectives in the debate on global food security, and from these perspectives, they proposed four types of key strategies: (i) technological strategies to increase production, (ii) socio-economic strategies to achieve equitable food distribution, (iii) strategies to promote local food movements, and (iv) economic, political, and regulatory changes to correct current market and food system imperfections and failures. In our view, these strategies are all needed simultaneously and in a coherent and orchestrated way to realize global food security in a sustainable manner.

Although one might intuitively think that the technological strategy to increase production might inevitably require an increase in internal and external resources (especially capital), amounts of many different resources (land, labor, energy) and inputs (fertilizer) will not increase; in fact, many resources (such as land, labor, chemical crop protectants, fertilizers) will most likely decrease (Struik et al. 2014; IPES-Food 2016) and become increasingly expensive (Robertson and Vitousek 2009; FAO 2011a). In fact, in several areas of this planet, the use of some of these resources will have to go down as part of "sustainable de-intensification". Declining resources necessitate achieving more production with the same amount of (or with less) inputs, i.e. increased resource use efficiency for global food security (Foley et al. 2011).

\section{Agricultural intensification contested}

In agriculture, producing more per unit of input (or maintaining production with less input) is called agricultural intensification (FAO 2004). However, there is a problem with such a general, technical definition. An increase in input of mineral fertilizer will increase the production per hectare and thereby intensify agricultural production as it will increase the production per unit of land and probably per unit of labor as well; at the same time, it will reduce the production per unit of fertilizer or per unit of cash, if other inputs are not increased (or at least optimized) at the same time, based on the Law of Diminishing Returns (Keating et al. 2010). This has a clear practical implication: the process of intensification does not improve the efficiency of all inputs at the same time and tradeoffs have to be considered when intensifying.

However, many contributors to the intensification debate assume a win-win situation, increasing productivity while simultaneously improving resource use efficiency and refraining from expansion of agricultural land. Mueller et al. (2012) claimed that there are large opportunities to reduce the impact of agriculture on the environment by eliminating the overuse of nutrients and changing water management. In contrast, Struik et al. (2014) argued that win-win situations are scarce in agronomy, while trade-offs (between the use of different resources, between different objectives, and between 
different values) are abundant. Van Noordwijk and Brussaard (2014) stated that closing the yield gap is not always associated with closing the efficiency gap.

Kuyper and Struik (2014) indicated that intensification has a Janus face, an expression they used to indicate that intensification has a dual, sharply contrasting effect on efficiency. This Janus face became especially evident since the 1950s, when, in many countries, traditional agriculture was revolutionized by rapid development of readily adopted new technologies, creating an industrial agriculture. The Janus face shows the two impacts of that industrialized agriculture: it enabled feeding the rapidly growing population by appropriating increasingly more natural resources, while, at the same time, it undermined the resilience of agricultural ecosystems and their capacity to feed mankind in the long run. This Janus face is an inevitable consequence of the original definition of intensification, which does not specify the nature of the inputs. Industrial agriculture increased production per unit land, but not necessarily per unit of externally applied resources. This Janus face ultimately leads to a contested agronomy (Sumberg et al. 2013b; Struik et al. 2014), i.e. an agronomy of which the theories, principles, objectives, methods, and technologies are challenged and debated. There are no easy solutions to mitigate the negative side of this Janus face. But there is a general sense of urgency, the more so as it threatens food security, creates injustice among different stakeholders, triggers mass migration, and induces other undesirable changes that are potentially near-irreversible. The problem also has an important temporal dimension: because the current situation is not sustainable, it also creates transgenerational injustice (Loos et al. 2014). Whatever happens, current agriculture must be transformed (Valenzuela 2016): it must be made "green" again.

\section{Making agriculture green again}

The term "green" in agriculture has developed over time. The phrase "Green Revolution" was coined by William Gaud in 1968 to describe the rapid development and uptake of new technologies in agriculture and especially in crop production, with an emphasis on the combined use of high-yielding varieties, mineral fertilizers, and agro-chemicals. The Green Revolution saved the lives of many people in developing countries, but was not "green" in the meaning usually assigned to the term today. Nowadays, "green" stands for environmentally friendly and sustainable, i.e. with a minimal impact on environment and ecosystems and therefore with judicious (and hence often limited) use of mineral fertilizers and chemical crop protectants, taking into account the values associated with food production and the rights of future generations to resources and adequate food.

Nowadays, we have the technology and knowledge to create a richer shade of green in agricultural production. Weekley et al.
(2012) described how a sustainable agriculture can be designed through the creation of so-called smart field technology platforms by combining environmental sensors (partly mounted to drones or through satellite vision), digital imaging, and data analysis, allowing subsurface precision soil management (including the soil meso- and microbiota) and plant-input delivery, based on real-time monitoring of soil, crop, and environment status.

As the sustainable intensification debate is partly rooted in debates over the Green Revolution, it comes as no surprise that the use of the qualifier "green" is prominent in the debate on future agricultural sustainability. Kuyper and Struik (2014) noted the plethora of qualifiers (Greener; Double-green; Evergreen; Real Green; New Green - or the Greening of the Green Revolution) as rhetorical devices in the discourse. In the spirit of that paper, we will use the qualifier "green" to reflect the required environmentally friendly and sustainable nature of agriculture and contrast light green and rich green futures for agriculture, depending on the nature and level of external inputs and on sustainability.

The overall goal of this paper is to describe the perspective of making agriculture green, i.e. environmentally healthy and sustainable, again. We divide that general goal into three aims:

(i) We will demonstrate that there are different routes to provide agriculture with a richer shade of green and to make it achieve what is needed: sufficient, safe and nutritious food produced in a morally acceptable way, based on equity, fairness and justice, and care for the future.

(ii) We will also try to provide a new perspective on agronomy and question the knowledge politics relevant to this field.

(iii) Finally, we will indicate how agronomy and sustainability education can contribute to developing a shared system of values that form the basis for a rich green agronomy.

In our discussions, we exclude farming systems that are foodinsecure. Farmers who do not produce enough food themselves or do not have access to enough food of adequate quality or sufficient natural resources to be free from hunger do neither have the luxury nor the obligation to improve sustainability and share resources with future generations, if those activities result in yield reductions for the current generation.

\section{Demonstrating different routes to "green" agriculture}

\subsection{Defining sustainability}

Sustainability is defined as the ability to continue defined behaviour indefinitely (Thwink.org 2014). The definition 
implies the ability of not being harmful to the external environment. In the case of agriculture, sustainability is the ability of farmers to continue harvesting crop and animal products without degrading the environment or the resource base while maintaining economic profitability and social stability. As such, the term sustainability describes the result of processes that achieve that purpose and the ability to permanently and indefinitely maintain the required quantity and quality of the resources. In practice, sustainability is often used as a synonym of sustainable development, the description of that process. Sustainable development is defined as development "that meets the needs of the present without compromising the ability of future generations to meet their own needs" (WCED 1987). Uphoff (2014), when discussing problems with defining sustainability, referred to different kinds of definitions:

(i) Extensional definitions, which do not define (describe in words or point out) as such, but list everything that falls under that definition

(ii) Intentional definitions, which specify the necessary and sufficient conditions for something to be sustainable

(iii) Ostensive definitions, which consist in pointing out conditions that we call sustainable (as we normally ostensively define the color green by referring to green objects rather than by defining green in terms of wavelength of visible light)

Ostensive definitions are most useful in cases where words do not work well, but where pointing out examples provide more insight. In practice, however, we use a negative ostensive definition of sustainability: from our observation of current practices, we can point out many examples that are evidently not sustainable (Bernard et al. 2014). From that negative ostensive definition, we describe pathways towards sustainability. Certainly, that kind of definition works best, as it accepts that many aspects of sustainability are currently unknown (and some even possibly "unknowable"; Wals 2015) and therefore allows us to consider sustainability and sustainable development as moving targets. But as a moving target, sustainability remains a contested concept (Sterling 2009).

The act of pointing out cases of (un)sustainability is not an exclusive task for scientists. Every person who is aware of the declining state of the planet Earth can point out cases of unsustainability. As this definition contains both normative and scientific aspects, it is necessary to introduce societal norms and values about what is acceptable from a cultural and behavioral perspective into the debate. Fischer et al. (2007) conceptualized a hierarchy of considerations within the ultimate biophysical limits of the planet Earth and introduced norms and values into the debate on sustainable intensification. Struik et al. (2014) also considered it necessary to introduce norms and values in the debate and conceptualized sustainable intensification not as a technological process but as "a process of social negotiation, institutional innovation and adaptive management".

If that more inclusive conceptualization is accepted, then sustainable intensification requires:

(i) Scientific consensus on (the hierarchy of) sustainability issues at stake, including indicators (Mahon et al. 2017), that can be applied to the diversity of farm types present and can capture aspects at different scales across time and space, but can also consider different dimensions

(ii) Societal debates resulting in shared values and norms to be taken into account

(iii) Institutional innovation to realize adaptive management and governance

Jackson et al. (2010) put emphasis on the capacity to change and claimed that "rapid changes in land use, food systems, and livelihoods require social-ecological systems that keep multiple options open and prepare for future unpredictability. We therefore need "sustainagility": "the properties and assets of a system that sustain the ability (agility) of agents to adapt and meet their needs in new ways"'. In agriculture, these new ways could, for example, include enhancing ecosystem services (thus supporting nutrient cycles; e.g. Brussaard 2012), enhancing resilience (creating persistence, adaptability, and transformability; Ge et al. 2016), and enhancing local food systems (Feenstra 2002).

\subsection{Agricultural sustainability is a complex problem}

Sustainability issues (and especially sustainable intensification) qualify as so-called wicked problems (Rittel and Webber 1973), i.e. problems that are poorly defined or even resist conventional definition and cannot be solved by science but can only be resolved through interactions with multiple stakeholders with conflicting perspectives.

Agricultural sustainability encompasses three dimensions, viz., environmental, social, and economic sustainability, but the debate on agricultural sustainability privileges either the environmental dimension (low environmental foot print) or the economic dimension (when pleas for sustainable intensification imply a business-as-usual scenario), whereas the social dimension (food security; human well-being) is often neglected.

Agricultural sustainability equally requires a balance between the objectives in the short term and those in the long run (Spiertz 2010). In this respect, the gap between what is done and what needs to be done to realize sustainability in agriculture is actually widening. Fischer et al. (2007) called this "the sustainability gap". Closing this gap requires a 
thorough analysis of concrete actions to be taken to maintain an "effective life-support system" (Fischer et al. 2007; Struik et al. 2014). The process of "agroecological engineering" (a term coined by Vanloqueren and Baret 2009), i.e. the design of productive, resilient, and sustainable agricultural systems based on agroecological principles, has indeed just begun.

\subsection{Intensification contested}

The often vague or imprecise definitions of intensification are part of the problem in the debate on sustainable intensification. Intensification is defined as increasing agricultural production per unit of input; often, but not necessarily so, this increase is per unit of land. Inputs are, however, much more diverse and can be part of the ecological resource base (e.g. land, water, nutrients), man-made (e.g. mineral fertilizer, crop protectants), or socio-economic (e.g. knowledge, labor). Intensification requires proper management and use of all inputs, certainly when they are expensive (cost reduction), are available in limited amounts (e.g. phosphorus, fresh water), are difficult to obtain (e.g. crop protectants in some developing countries), or behave in a complex manner in the agroecosystem (e.g. nitrogen). Proper management also includes avoidance and management of risks, for example, the risk of reduction in water quality by rapidly changing inputs of nitrogen and phosphorus fertilizer (Bouwman et al. 2017). In many agricultural situations, intensification is actually associated with increases in inputs, not with reductions, in order to produce more per unit of the same or other inputs. The science and practice of optimum management of internal and external resources is central in agronomy and farming, respectively.

Many claim that there are strong agronomic arguments for realizing intensification by increasing inputs. Struik et al. (2014) stated — based on the seminal paper of De Wit (1992) on resource use efficiency in agriculture - that: "The totality of resource use is most efficient when all inputs are applied in quantities that are close to the level at which yields are maximized. This translates into land use efficiency, water use efficiency, and nutrient use efficiency. Intensification (here interpreted as increase in agricultural production per unit of land) improves the efficiency of resource use".

Some forms of intensification, e.g. the increase of agricultural production per unit of land and per unit of labor, can only be achieved by increasing other inputs. With agriculture becoming less attractive as an occupation (and the younger generation increasingly moving to urban centers), yield increases per unit labor through external inputs are equally imperative. In many parts of the world, this intensification by increasing external inputs is a feasible and productive option, either because the current levels of other kinds of inputs (e.g. seed, knowledge) are already so high that the external inputs will be used efficiently or, in contrast, because the base level of the external inputs is so low and the availability of other resources (land and/or labor) is reasonably high that one can profit from the strong response to input level in the lower range of input availability. In other parts of the world, the Law of Diminishing Returns of inputs takes its toll in terms of decreased resource use efficiency.

\subsection{Efficiency contested}

Efficiency is a concept that relates achievement of goals to the effort needed and, as such, depends on the relevance and hierarchy of goals across scales; "efficiency" is not an inherent property that travels well: efficient subsystems may not lead to an efficient overall system (Van Noordwijk 2017). The road towards an inclusive efficiency, based on "Planet first," is difficult as it requires a different way of agronomic (e.g. Zhang et al. 2015) and economic (e.g. Raworth 2017) thinking.

Resource use efficiency in agriculture is a complex concept. While it has been defined in many different ways, we describe it as the combined effect of the efficiencies in capturing a specific resource, incorporating it, using it, and making it productive. In common agricultural practice, yield gaps, differences between theoretical yield levels and actual farmers' yield (Van Ittersum et al. 2013), are considerable, but agronomic nutrient use efficiencies (an element of resource use efficiency) are sometimes extremely low (Spiertz 2012). Often, efficiency gaps are also large, resulting in large environmental impacts (Van Noordwijk and Brussaard 2014). De Wit (1992) claimed that "farmers should aim at the minimum input of each resource required to allow maximum utilization of all other resources". This statement, however, does not apply to all types of resources used as inputs in agroecosystems (Struik et al. 2014). Like agricultural sustainability, resource use efficiency has many dimensions: agronomic, environmental, economic, social, trans-generational, and global ones. These different dimensions are scale-dependent. There are no intrinsic reasons why one dimension should be privileged. In practice, farmers manage their farms with a wider perspective than merely optimizing the economic yield of a single crop or field; and they do so for good reasons. Resource use efficiency in that wider sense is one of the main drivers of the actions of a farmer.

Yet, current agronomy tends to reduce the concept of resource use efficiency to one privileged dimension, the agronomic efficiency, thereby recommending one specific pathway of (sustainable) intensification. Because of this privileged dimension of agronomic efficiency, current agronomy is contested (Sumberg et al. 2013b). Moreover, it is important to realize that farmers, as primary producers, are only the first link in a value chain of agricultural production and that the efficiency of the use of resources can also be applied to the entire value chain, from field to fork. Van Bueren et al. (2014) clearly indicated how complicated and specialized a value 
chain of agricultural products can become. They used the example of chicken meat production by rearing broilers. Chicken meat production systems have, compared with many other animal meat production systems, a low carbon footprint. However, the broiler meat value chain has at least 40 different specialized links that behave as a network of many separate subsystems (Van Bueren et al. 2014). Different links in the value chain primarily interact with actors immediately upstream or downstream the value chain, and the main driver is economic efficiency, at the expense of other forms of efficiency. Since these actors do not have influence on what is happening farther upstream or downstream, the value chain in its entirety is very difficult to manage: intensification takes place at the level of each individual link, even when this is not beneficial for the intensification of the entire chain. Creating organized responsibility for maximizing efficiency of the entire chain instead of striving towards efficiency of the individual link is an enormously complicated challenge.

Statements on positive effects of high levels of input, cited above, in fact reflect a certain type of "win-win euphoria" (Kuyper and Struik 2014), popular among not only agronomists and farmers but also policy makers who mainly argue based on economic efficiencies of input use. But the connection between increased inputs and increased resource use efficiency goes against the Law of Diminishing Returns: for a single input, the highest increment of output per increment of input is reached at lower ranges of input (Keating et al. 2010). Moreover, aiming at high economic efficiency without taking costs of externalities into account does not fit in the pursuit of a richer green agronomy and agriculture. For that reason, the search for another form of intensification started: a form of intensification that creates "eco-efficiency". The term ecoefficient has been coined by Keating et al. (2010). It indicates the production of food and other products relative to the ecological resources used as inputs, including land, water, nutrients, energy, and biodiversity, but also other types of resources, including labor and capital, while taking into account environmental footprints or ecosystem services.

\subsection{Sustainable intensification}

As the above sections have indicated, both the concepts of (agricultural) sustainability and intensification are ambiguous. It is therefore not surprising that the combination of both terms (the noun intensification with the adjective sustainable) is apparently even more confusing (Uphoff 2014). Moreover, the two words "sustainable" and "intensification" in the phrase "sustainable intensification" are often not assigned equal weight (Garnett and Godfray 2012). How complex or vague the concept of sustainable intensification is, has been clearly demonstrated by Petersen and Snapp (2015) who interviewed 30 agricultural experts on the topic. These authors observed that respondents interpreted the term differently, partly because they considered "sustainable" to be vague, and most respondents did not observe a significant departure from current practices. These observations brought the authors to suggest "ecological intensification" as an alternative concept.

Wezel et al. (2015) identified three major concepts of intensification, i.e. sustainable intensification, ecological intensification, and agroecological intensification, but noted that all three concepts are actually poorly or imprecisely defined, often misused, or unclear in their practical implications. They tried, in a comparative manner, to analyse the three concepts, the use of these terms, their definitions and the underlying principles, practical implications, and operationalization, both in agricultural practices and in policies or laws. They observed some differences in these three major concepts. Like Petersen and Snapp (2015), they concluded that sustainable intensification is generally and imprecisely defined and tends towards business-as-usual, much more so than the other two concepts that seem more nuanced and more explicitly defined. Ecological intensification puts more emphasis on ecological processes in agroecosystems. Agroecological intensification appears to be more explicit on systems analysis and includes more specifically cultural and social aspects. From these papers, it is obvious that sustainable intensification has become degenerated into a vague phrase that can be used and abused too easily.

Many proponents of sustainable intensification put the emphasis on intensification, while sustainable is only a buzz word, based on the claim that intensive is more sustainable than ecological, organic, or low input, i.e. it is often an excuse for business-as-usual, with the rather empty promise that at least the amount of output per unit of input is maximized. The claim is based on a production-oriented analytical framework that ignores externalities and suggests that the yield per unit of input increases with an increase in the level of input (e.g. Chapagain and Good 2015). This is often the case over a wide range of inputs starting from a low fertility or low water availability. However, closing the yield gap in such conditions may either increase or decrease the resource use efficiency gap (Van Noordwijk and Brussaard 2014). At higher levels of input, the resource use efficiency surpasses its theoretical upper limit (Zhang et al. 2015). Van Noordwijk and Brussaard (2014) suggested that the yield gap and the efficiency gap are partially independent, leaving opportunities for synergies in closing these two gaps.

Like sustainable economic growth (Trawick and Hornborg 2015), sustainable intensification as usually understood has become an oxymoron, i.e. an ostensible self-contradiction, because intensification cannot be achieved in a sustainable way. Sustainable intensification suggests an acceptable practice for something that cannot be achieved or maintained, based on the fact that metrics are used that do not take into account important negative elements in the economic and ecological cost-benefit equation (Mahon et al. 2017). The question is whether there is a way out of this quagmire and 
whether we, given the obvious problems with clearly defining it, can circumscribe sustainable intensification in useful ways. Rather than providing definitions, we prefer a brief historical excursion to the origin of this and related concepts and will use that historical perspective as a means to clarify the concept of sustainable intensification.

Pretty (1997) coined the term sustainable intensification first to describe the need for increases in yield (output per unit area of land) while also benefitting the environment and the economy in sub-Saharan Africa, an area with large yield gaps. See Fig. 1 for an example on resource mobilization in lowinput agriculture in southern Ethiopia. The picture shows how resource-poor farmers align the remaining stover along the original crop rows, especially on the slopes, to maximize the resource use efficiency. Pretty (1997) considered the participation of smallholders essential in developing productive, locally adapted technologies. Later, the same author (Pretty 2008) widened the definition of sustainable intensification: "Intensification using natural, social and human capital assets, combined with the use of best available technologies and inputs (best genotypes and best ecological management) that minimize or eliminate harm to the environment". But also, here, the output site of the equation merely contains produce and environmental impact. Still later, Pretty et al. (2011) and Firbank et al. (2013) stretched that definition to "producing more output per unit of land while reducing environmental impacts and increasing contributions to natural capital and flow of environmental services". Gradually, the concept of sustainable intensification has apparently been widened to also include (industrial) agriculture in the developed world and to provide connections between current and future practices without being disruptive. Currently, the term is most often used for industrial agriculture, and sustainable intensification by smallholder farmers in the global south is now more often referred to as ecological intensification (see below).

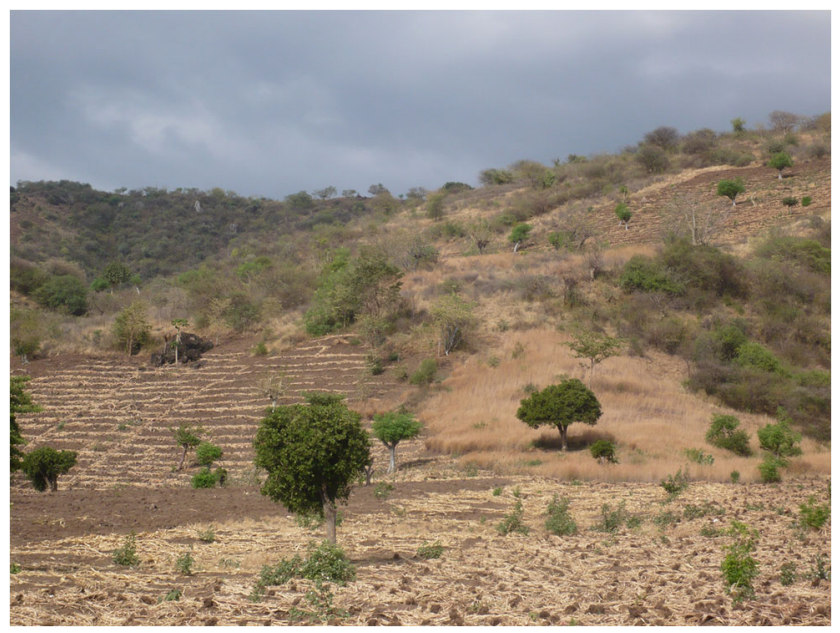

Fig. 1 Managing sorghum crop residues in dryland farming in Konso, Southern Ethiopia. Photo: Paul C. Struik, Wageningen University and Research, Wageningen, the Netherlands
Agricultural economists like Ruben and Lee (2000) defined sustainable intensification as "the simultaneous increase in returns to land and labor (in the short run) and the maintenance of soil nutrient balances (in the long run)". This definition restricts sustainability to very specific types of inputs and resources. Wezel et al. (2015) referred to a recent and widely cited definition of sustainable intensification by FAO (2011b): "producing more from the same area of land while conserving resources, reducing negative impacts on the environment and enhancing natural capital and the flow of ecosystem services". This link with ecosystem services brings the definition much closer to that of ecological intensification (see below).

Altieri (2012) has protested against, in his eyes, abuse of the term sustainable intensification. In his view, sustainable intensification unrightfully reframes the debate on what agricultural practices are agroecologically sustainable by "stripping off their social and political content". Loos et al. (2014) also argued that the term sustainable intensification is potentially misleading because central tenets of sustainability are not adequately addressed. Smith et al. (2017) tried to broaden the concept of sustainable intensification by including the human condition, nutrition, and social equity and tried to identify indicators and associated metrics, but noted that most current indicators are static and are for that reason difficult to use for evaluating pathways towards sustainability.

In this sense, the problem with the framing of sustainable intensification is huge: in many framings, there is a blind spot for norms, values, human well-being, and justice. Especially, the justice element is crucial: it concerns intra- and intergenerational distributive justice (ensuring a socially just distribution and allocation of resources and food among people of the same generation and among generations) and procedural justice (i.e. the participatory governance by and empowerment of individuals, communities, and societies to decide how their needs are to be met) (see Agyeman and Evans 2004; Loos et al. 2014).

\subsection{Ecological intensification}

A common definition of ecological intensification is from Cassman (1999). He stated that the goal of ecological intensification in agriculture is "further intensification of production systems that satisfy the anticipated increase in food demand while meeting acceptable standards of environmental quality". This definition comes close to continuation of "business-as-usual" in agronomic practice without the negative side effects. Cassman (1999) mentioned three pillars for ecological intensification: increasing yield potential, maintaining or improving soil quality, and ensuring highly efficient use of inputs and minimum loss of inputs to the environment by precision agriculture, i.e. optimizing field level management by using site-specific information, decision support systems, and detailed information on 
weather. Given those pillars, Cassman (1999) also noted the need to distinguish between strategies for ecological intensification under favorable and unfavorable conditions, for example, different strategies for irrigated and rain-fed conditions. Less-endowed regions such as Sub-Saharan Africa are absent in this paper. Tittonell and Giller (2013) equally noted that "ecological intensification has seldom been addressed in the context of smallholder farming systems of rural Africa".

Cassman's definition pertains to already highly productive agricultural systems where he envisaged even further intensification without further degradation (or even a reversal of degradation) of the resource base. However, subsequent authors have brought ecological intensification, with its clearer emphasis on ecological principles as a basis for agriculture, much more in the realm of less industrialized agricultural systems, where, in the absence of external inputs, farmers have to rely more on the productive internal resources or where farmers willingly reduce external resources as in organic agriculture. In ecological intensification, the aim is to make use of inputs in a very efficient way by applying knowledge and understanding of the ecological processes, their uptake by the plant, and their yield benefit per unit of resource taken up. Or, as noted by Levain et al. (2015), ecological intensification is intensification in the use of natural functions provided by ecosystems. Brussaard et al. (2010) and Tittonell and Giller (2013) have demonstrated how the use efficiencies of inputs and other resources can be increased in ecological intensification.

Tittonell (2014) defined ecological intensification as "the means to make intensive and smart use of the natural functionalities of the ecosystem (support, regulation) to produce food, fiber, energy and ecological services in a sustainable way". This definition refers to making better use of nature to design production systems and of the possible synergies between food security, global change adaptation, and mitigation but also extends primary production to ecosystem services in addition to food. It reflects an optimistic view on the resilience of "nature" in a production environment. It also brings the qualifier "sustainable" in through the back door.

In ecological intensification, agricultural systems are designed for benefitting from ecological processes and functions, including biological control of biotic stressors and efficient use of available resources and ecological services. Often, ecological intensification aims at increasing primary production per unit area while sustaining the systems' capacity to produce, which requires an ecology-intensive agronomy. However, the terminology sometimes suggests normative use of ecological concepts (where the hypothesized positive relations between diversity, productivity, and stability are perceived as inherently worthwhile), which may make such definitions liable to accusations of the naturalistic fallacy (i.e. arguing from "is" to "ought"). Denison and McGuire (2015) equally noted this issue, arguing that there is no logical argument why natural ecosystem organization of agricultural systems is intrinsically better than that of human-designed systems, especially when we evaluate them according to criteria that are relevant for agronomy and agriculture.

Milder et al. (2012) described agroecological intensification as follows: "agroecological intensification integrates ecological principles into agricultural management to reduce dependency on external inputs and increase the productive capacity of biotic and abiotic system components". Agroecological intensification according to Wezel et al. (2015) specifically addresses social-cultural aspects and also includes (intensification of) farmers' knowledge and a systems approach, but that did not prove to be helpful in developing strong criteria to make a distinction between sustainable, ecological, and agroecological intensification, except perhaps for the intensity with which ecological principles are integrated into farms and systems management (Wezel et al. 2015).

\section{Redefining agronomy}

\subsection{How to cope with contested concepts?}

Overviewing the debate in the literature on sustainable intensification one easily becomes cynical. It seems that the term was initially coined to stress the need to change the nature of agriculture in Sub-Saharan agriculture, but that the term was subsequently "hijacked" by proponents of the western highinput agriculture to demonstrate that input-intensive agriculture is the most environmentally friendly solution to realize food security. But we need to do more than to reframe sustainable intensification "beyond unreasonable doubt" (a term coined by Wals (2015)). Also, the concept of ecological intensification changed its meaning (Kuyper and Struik 2014), from a way to increase food production while meeting acceptable standards of environmental quality (Cassman 1999) to intensification making use of agricultural practices that are inspired by (or even mimic) nature (Doré et al. 2011). But the opposition remained. With that opposition came also different further claims about business-as-usual versus the need for paradigm shifts. This juxtaposition of terms with malleable meaning therefore suggests a deeper need for two contrasting terms about processes: one that starts with already highly intensive agriculture (where it may equally be claimed that a form of de-intensification is required to become sustainable) and one with agriculture that is confronted with large yield gaps (and hence food insecurity for a rapidly growing population). Both forms make claims about a universal recipe on the one hand but also claim context-dependency of specific practices that follow from the need for intensification on the other hand. The impact of scale on sustainable intensification is also an important issue (Kuyper and Struik 2014). When 
can small scale be more durable than large scale and when is the opposite valid? What scale of management is required to give ecology a fair chance to intensify our often fragmented agriculture? How can knowledge politics play a role?

It may not be useful to define the terms sustainable intensification and ecological intensification as Wezel et al. (2015) did. Contested concepts do not disappear by better definitions because they are inextricably linked to choices for different practices, and these practices remain contested. Of course, not every author who uses the term sustainable or ecological intensification can be placed at the extreme of this axis of two forms of intensification; middle ground is common. We therefore have to accept that authors use different terms while essentially referring to similar processes or use the same term, despite clear differences in their view on the future of agricultural intensification. Discussions on (ecological or sustainable) intensification take place in a political arena that determines whose agronomy counts. For example, how to deal with the following complex issue: to what extent do we need to maintain the multi-functionality of agroecosystems for future generations? Should we go for an agriculture based on ecological intensification (as defined by Doré et al. 2011) and on clear principles and frameworks of settling trade-offs?

\subsection{Why sustainable intensification should go green}

Tittonell and Giller (2013) stressed that for African smallholder agriculture intensification, whether conventional, sustainable, or ecological is simply a necessity. This is not a simple proposition: input markets are often poorly functional, and markets of agricultural produce are also not functioning well; markets can collapse when smallholders manage to realize increases in yields; moreover, smallholders often lack the means to invest in expensive resources such as high-quality seed, fertilizers, or chemicals and the use of such inputs and the technologies to apply them can also be inadequate, while labor requirements also limit a rapid shift to higher output levels.

Knowledge and understanding usually require site-specific insights. Farmers have been developing site-specific knowledge for centuries and have been capable of working with that knowledge based on expertise, experience, and experiential learning. Ecological intensification requires more contextualized knowledge than conventional intensification. Ecological intensification might profit from a trait-based ecology approach, i.e. an approach in agroecology based on plant functional traits (Garnier and Navas 2012; Martin and Isaac 2015). A good example of trait-based ecology in agroecosystems within the context of this discussion is the design of a proper balance between the architectural above-ground and belowground characteristics of intercrops based on accurate knowledge on the dynamics of weather conditions, temporal and spatial availability of resources (such as nutrients, light, water), and disease pressure in such a way that a system is created, which enhances stability of productivity, increases tolerance to abiotic and biotic stresses, enhances resource use efficiency, and increases ecosystem services. Trait-based ecology puts functionality at the fore and creates a stable agroecosystem by combining the traits that are required to reach that stability in the simplest possible way.

Trait-based ecology could apply at various scales, i.e. with crops on field scales and with cropping systems on regional or landscape scales to global plant production systems, and could be considered as a multi-scale approach towards making sustainable intensification green. Trait-based agroecological research should include, among other aspects, novel approaches to plant breeding, quantification of dynamics of processes in the agroecosystem (e.g. measuring activity of soil microbiota during the growing season based on smart farm technology; Weekley et al. 2012), maintenance of associated biodiversity, quantitative analysis of contributions of agroecosystems to global net primary productivity and other biogeochemical cycles, agricultural vulnerability to climate change, and the impact of agriculture on climate change. Further options would include systems breeding (Lammerts van Bueren 2016) and crop design (or design of mixed cropping systems).

Many ideas and theories of ecological intensification still lack proof. For example, it is still difficult to directly link biodiversity to resource use efficiency, yield increase, or resilience. Yet, a recent review suggested that intercropping can play a significant role in sustainable intensification (Brooker et al. 2015). See Fig. 2 for a diverse intercropping system in China. Another recent study across different countries demonstrated that crop diversification is an important tool in ecological intensification (Gurr et al. 2016). An international panel of experts concluded that "diversified agroecological systems" can perform equally well as "industrial food systems" in terms of yield (IPES-Food 2016). Not everyone

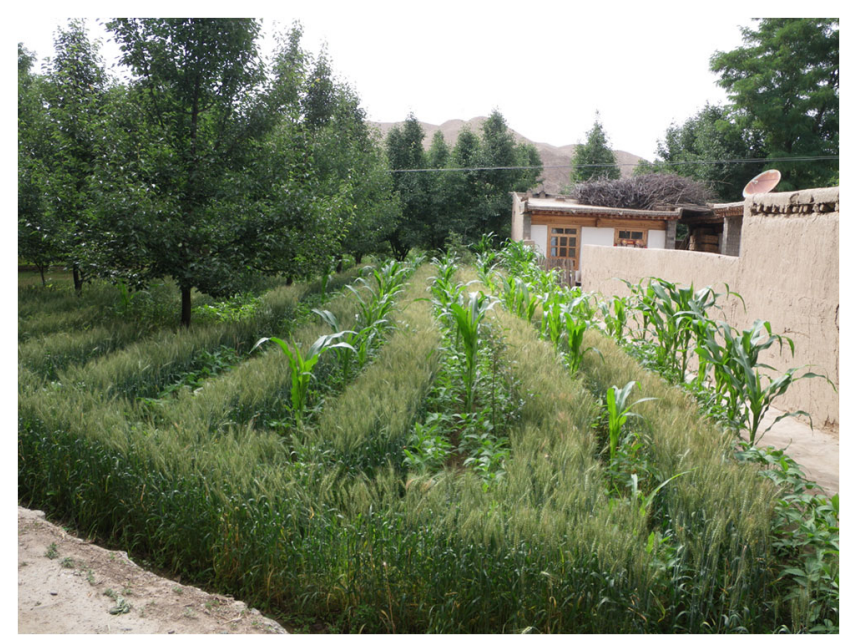

Fig. 2 Complex intercropping systems in China. Photo: Wopke van der Werf, Wageningen University and Research, Wageningen, the Netherlands 
is optimistic: Sadras and Denison (2016) stated that there is a dual barrier (both biological and agronomical) to optimize crops and cropping systems. Optimization of single crop traits (e.g. leaf angle) or single agronomic practices (e.g. fertilizer rate) is impossible due to trade-offs and environmental variation. They concluded that neither crop genetics nor crop management can be optimized; removing agronomic barriers for sustainable intensification is therefore complicated.

Nevertheless, many take it for granted that resilience through diversification is a key element in sustainable intensification (Garnett et al. 2013). There is certainly a need to pay more attention to resilience, including persistence, adaptability, and transformability, of agricultural production systems by enhancing resilience thinking in order to reduce the vulnerability of those systems (Ge et al. 2016; Urruty et al. 2016). Resilience thinking, including ecological resilience and engineering resilience (Holling 1996), should include the cropping system, the farm, the agroecosystem and the food system, and the needs to develop beyond abstract conceptualization towards concrete operationalization. For recent overviews of the conceptual frameworks of resilience thinking, see also Walker and Cooper (2011), Baduhur et al. (2013), Garmestani and Benson (2013), and Anderson (2015). Ignoring trade-offs will likely make intensification less sustainable, and taking them into account offers opportunities to make intensification ecologically more sound.

\subsection{The social dimensions of sustainable intensification}

Based on the above, we argue that sustainable intensification requires a different conceptualization. It should be considered as an intellectual framework or a process of enquiry and analysis for navigating and sorting out the issues and concerns in agronomy, followed by implementing the outcome of this process for education, extension, action, and continuous societal debate. Such an intellectual framework is also needed, because there are forces that create "unreasonable doubt" about the impact of sustainable intensification, just as has occurred in the climate change debate (Wynne 2010).

Sustainable intensification requires radical transformations in the social and economic organization of agriculture, based on equitable distribution, individual empowerment, and justice. Creating such change will be challenging since dominant socio-technical configurations are maintained in current institutions and kept intact by strong lobbies (Vanloqueren and Baret 2009; Struik et al. 2014; Fraser et al. 2016; IPES-Food 2016). Science must contribute more than knowledge: norms and values are also at stake and need to play a major role in decisions on the way forward. Sustainable intensification requires societal debates and transparent decision-making about what can and should be intensified, based on the fact that trade-offs are common. Moving towards agricultural sustainability makes it mandatory that we improve our analysis of trade-offs first.

The basic question for now and in the future is: can the right to food be realized in a sustainable way? The right to food is defined as "the right of every individual, alone or in community with others, to have physical and economic access at all times to sufficient, adequate and culturally acceptable food that is produced and consumed sustainably, preserving access to food for future generations" (De Schutter 2014). This right to food is automatically linked to the way it is produced and used: the right is only applicable if the food is produced and consumed sustainably. This conditio sine qua non adds a strong normative aspect to the right to food and to food security in general. Sustainable food security has certainly more to do with the justice of food distribution and the equity of resource distribution for food production than with the volume of food production itself.

Our considerations in Sections 4 and 5 are summarized in Fig. 3, showing the required inputs for an inclusive conceptualization of agricultural sustainability. Figure 3 should be read from left to right and from right to left. From left to right, it describes the contribution of agronomic (technical) science and education to agronomic sustainability and its components, demonstrating that there are technological trade-offs to be taken into account. From right to left, the figure integrates the input of biophysical science and education and social science and education into the societal debate on how society wants its food to be produced, taking into account the biophysical limits of the planet Earth, societal justice for all current and future stakeholders, and options of institutional innovation and adaptive management. This results in integration of biophysical indicators on the one hand and norms and values on the other hand that together prompt to assessing a hierarchy of sustainability issues and starting social negotiations. The outcome is, again, a set of trade-offs. Combining the latter trade-offs with the agronomic trade-offs results in an inclusive concept of sustainability that shows the way to either sustainable deintensification or sustainable intensification. Note that the processes indicated in the scheme work best if from the very early start the agronomic science and education on the left interact with the biophysical science and education and the social science and education on the right.

\section{Describing the need for a link between agronomy and education in sustainability}

\subsection{A new agronomy and a new role for agronomists}

In the new role of advocate of sustainable intensification in the ecological sense, agronomy will have to be an art, a science, a skill, and a driver of social innovation, all at the same time. Agronomy is an art, as it requires a creative balance between 


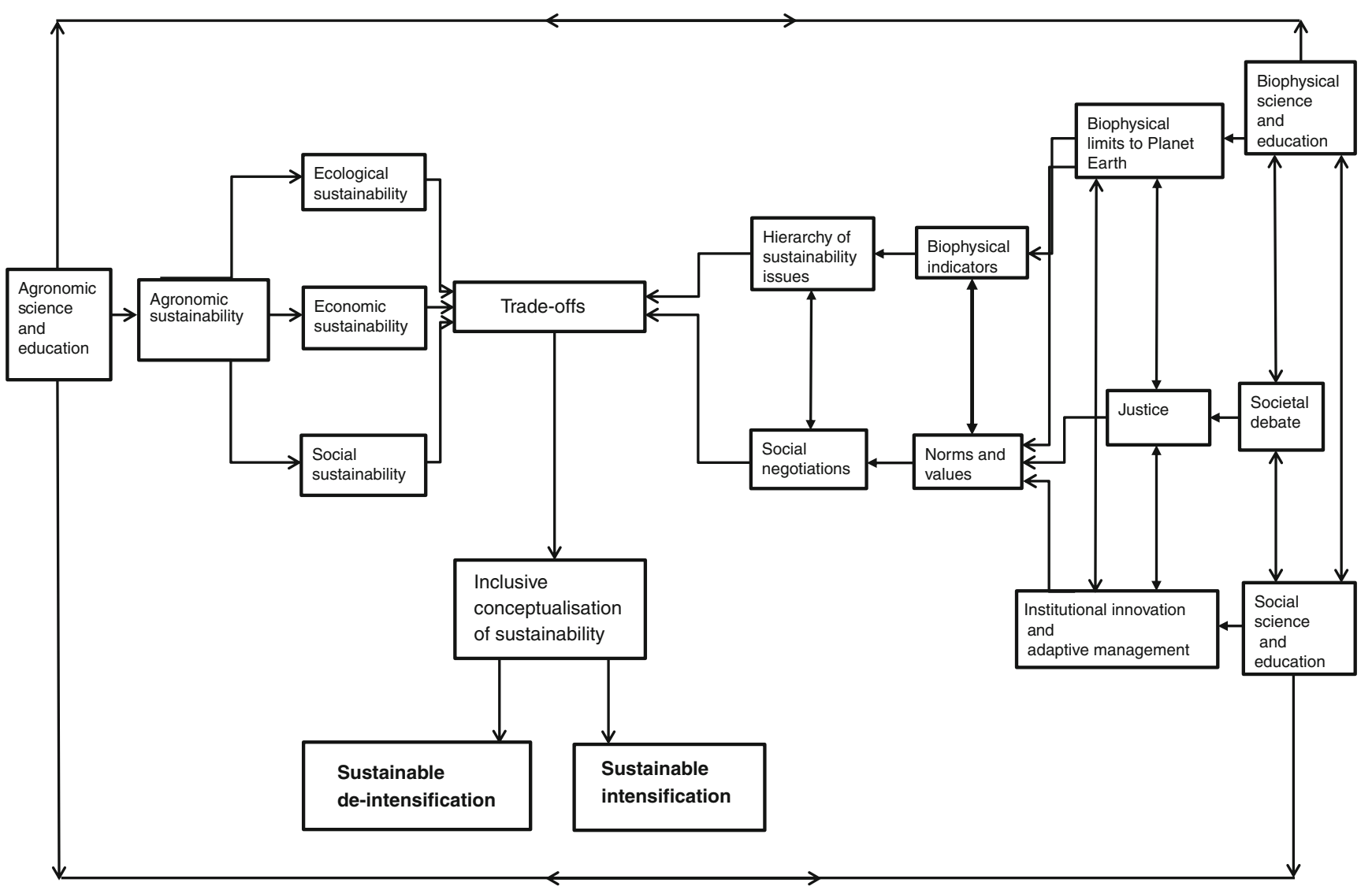

Fig. 3 Inputs required for an inclusive conceptualization of agricultural sustainability

vision, expertise, knowledge, insight, predictive power, and courage. Agronomy is an applied science based on physical, chemical, biological, socio-cultural and economic insights, knowledge, and expertise. Agronomy is a skill and a type of experience that needs to be transferred from generation to generation. Agronomy should create innovation by overcoming epistemological boundaries between the natural and social sciences. As a science, agronomy should train crop generalists who can shift gear from any level of aggregation to the crop level or the cropping system level, apply knowledge at different levels of aggregation, contextualize and triangulate knowledge, design tools to translate knowledge, and design cropping systems. Key elements of agronomy as a science are inclusiveness, (comparative) analysis through experimentation and modeling, asking the right questions (conceptualization), interpreting and evaluating information (framework), aggregating (models), application (decision support), generalization and contextualization, extrapolation, and design.

\subsection{Education}

Sustainable intensification requires new sources of knowledge and new methods in agronomy (Doré et al. 2011) but also education in social aspects of sustainability, as sustainable intensification is especially about societal negotiation, institutional innovation, and adaptive management, rather than an exclusive property of agronomic discourse. Geertsema et al. (2016) referred to this concept as actionable knowledge. We will have to teach agronomy students and the general public that a more normative (or value-laden) agronomy is unavoidable. We should re-invent and re-define agronomy as an interdisciplinary science, integrating natural and social sciences, with new curriculum development that acknowledges that agriculture poses an enormous pressure on available resources and that that pressure needs to stay within planetary boundaries. Agronomy can provide options and quantify trade-offs so that society can make educated decisions on trade-offs.

In addition to this challenge of transforming ourselves from wrongdoers into educators, we also have the problem that it is difficult to design such a curriculum. Wals (2015) argued that the ill-defined nature, the contestation, and commodification of sustainable development and education for sustainable development could easily become an excuse not to engage with education in sustainability. This makes teaching sustainability a challenge, yet sustainability education is imperative. A key issue here is who orchestrates how ideas are created, used and disseminated, and who manages the transfer of these ideas to create social change. The goals, priorities, methods, results, and validity of agronomic research in developing countries have 
become considerably contested, because of the "neoliberal time in economic and social policy and the rise of prominence of the participation and environmental agendas" (Sumberg et al. 2013a). But also in the developed world is agronomy strongly contested (Sumberg et al. 2013b; Struik et al. 2014). Do science and education (including agronomic science and education of which the theories, principles, objectives, and methodologies are challenged, debated, and even contested) have the scientific and the exclusive moral authority to play the required role in enhancing the processes towards an inclusive concept of sustainability as described in Fig. 3 ?

Despite the need to be humble, there are important developments towards new ways of training future agronomists/ agroecologists. Especially in Nordic universities, lecturers and students have been experimenting with novel educational strategies. Lieblein et al. (2012) indicated that action learning and action research with stakeholders can greatly contribute to higher education in agricultural and food sciences and support experiential learning (cf. Kolb 1984). They evaluated the involvement of non-university stakeholders in courses or research programs of Nordic universities and concluded that such an involvement could serve four purposes:

(i) It enables understanding of complex topics, often unique in context and location

(ii) It enhances reflection on real-life situations which is motivating for students

(iii) It helps to connect university with society

(iv) It creates social relevance and civic engagement

Francis et al. (2017a, b) described 12 educational strategies to educate future agroecologists based on the same experiences with Nordic universities. In brief, these strategies can be described as:

1. Using holistic, ecological principles to design future farming and food systems.

2. Using novel, creative tools, based on multidimensional methods, to assess sustainability of farming and food systems.

3. Using multi-stakeholder involvement to develop shared values and goals of all agents in the farming and food systems.

4. Using indigenous knowledge and experience to create useful interaction between theory and practice towards farm system design.

5. Using holistic approaches in studying, understanding, and designing food systems.

6. Creating and catalyzing a "dialogue space" between science and practical experience to initiate efficient experiential learning.

7. Integrating discipline-derived components of knowledge and experience into a discovery process towards scenarios that can describe the entire farming and food systems.

8. Using organic farming as a working model for sustainable farming and food systems.

9. Using contemporary and local resources in food systems.

10. Creating abilities for autonomous, life-long, social learning.

11. Recognizing and valuing student experiences as significant contributions to team learning.

12. Enabling students in learning for responsible action.

These strategies have in common that they stimulate interaction between science and practice, reflection, dialogue, action-oriented participation, and observation, i.e. they ensure that the agronomy becomes less contested.

Other examples of innovative and holistic learning in agroecology education exist in other parts of the world as well, e.g. in France (Ferrer et al. 2017) and in the USA (Francis et al. 2017a, b). Also within our own university, Wageningen University, Wageningen, the Netherlands, there are optional programmes on agroecology within the international MSc curriculum on organic agriculture, which are based on holistic, multidisciplinary approaches geared towards the analysis and design of sustainable organic farming systems through action research.

\section{Conclusion}

Society needs dynamic coalitions and flexible decisions, an agriculture demonstrating flexibility to cope with future change, and a sustainability that is perceived as a moving target. Society needs different conceptualizations (but not definitions) of sustainable intensification for different parts of the world, in different shades of green, but developing towards the richest green possible. We admit that current agriculture tends to become more industrial; in that process, it is likely that agriculture will become less sustainable, resulting in an increase in the sustainability gap. We do not need to accept that apparently the only form of further intensification consists of increased (and sometimes more efficient) use of external input resources (capital, fertilizers, crop protectants) at the expense of the natural resource base.

As argued in the Sections 4.3 and 4.4, there is a strong contrast between sustainable intensification in high-externalinput agriculture of the developed world (including India and China) and that of the low-external-input agriculture in many developing countries. Globally, agriculture will become greener, i.e. more sustainable, if the following two trends will coincide: sustainable de-intensification in the industrial 
agriculture of the north and sustainable intensification of the low-input agriculture of the south. The question then is whether these systems will (and should) converge towards one generalized system of sustainable agriculture. In our view, they will (and should) not come together as the ecological conditions and the resource base are and will remain too different. They will likely also not converge because some forms of sustainable intensification are evidently more local or territorial than others (Cunningham et al. 2013; Duru et al. 2015).

Agronomists should develop into knowledge brokers with a well-developed antenna for the social dimension of sustainability, created on the basis of academic curricula that pay adequate attention to the unknowns of sustainability. Agronomists can play a key role in the implementation of the knowledge politics that will lead to the development of a widely shared system of values that form the basis for a rich green agronomy. With a convergence of values, agriculture will become less contested.

Acknowledgments The authors are grateful to the reviewers and editors for their detailed, constructive, and useful comments on an earlier version of the manuscript. We thank our colleague Wopke van der Werf for the photograph of Fig. 2.

Open Access This article is distributed under the terms of the Creative Commons Attribution 4.0 International License (http:// creativecommons.org/licenses/by/4.0/), which permits unrestricted use, distribution, and reproduction in any medium, provided you give appropriate credit to the original author(s) and the source, provide a link to the Creative Commons license, and indicate if changes were made.

\section{References}

Agyeman J, Evans B (2004) "Just sustainability": the emerging discourse of environmental justice in Britain? Geogr J 170:155-164. doi:10. 1111/j.0016-7398.2004.00117.x

Altieri MA (2012) Convergence or divide in the movement for sustainable and just agriculture. Sustain Agr Rev 9:1-9. doi:10.1007/97894-007-4113-3 1

Anderson B (2015) What kind of thing is resilience? Politics 35:60-66. doi:10.1111/1467-9256.12079

Baduhur AV, Ibrahim M, Tanner T (2013) Characterising resilience: unpacking the concept for tackling climate change and development. Clim Dev 5:55-65. doi:10.1080/17565529.2012.762334

Bernard F, Van Noordwijk M, Luedeling E, Villamor GB, Sileshi GW, Namirembe S (2014) Social actors and unsustainability of agriculture. Curr Opin Env Sust 8:155-161. doi:10.1016/j.cosust.2014.01. 002

Beroya-Eitner MA (2016) Ecological vulnerability indicators. Ecol Indic 60:329-334. doi:10.1016/j.ecolind.2015.07.001

Bouwman AF, Beusen AHW, Lassaletta L, Van Apeldoorn DF, Van Grinsven HJM, Zhang J, Van Ittersum MK (2017) Lessons from temporal and spatial patterns in global use of $\mathrm{N}$ and $\mathrm{P}$ fertilizer on cropland. Sci Rep 7:40366. doi:10.1038/srep40366

Brooker RW, Bennett AE, Cong W-F, Daniell TJ, George TS, Hallett PD, Hawes C, Iannetta PPM, Jones HG, Karley AJ, Li L, McKenzie BM, Pakeman RJ, Paterson E, Schöb C, Shen J, Squire G, Watson CA, Zhang C, Zhang F, Zhang J, White PJ (2015) Improving intercropping: a synthesis of research in agronomy, plant physiology and ecology. New Phytol 206(1):107-117. doi:10.1111/nph.13132
Brussaard L (2012) Chapter 1.3. Ecosystem services provided by the soil biota. In: Wall DH et al (eds) Soil ecology and ecosystem services. Oxford University Press, Oxford, pp 45-58

Brussaard L, Caron P, Campbell B, Lipper L, Mainka S, Rabbinge R, Babin D, Pulleman M (2010) Reconciling biodiversity conservation and food security: scientific challenges for a new agriculture. Curr Opin Env Sust 2:34-42. doi:10.1016/j.cosust.2010.03.007

Cassman KG (1999) Ecological intensification of cereal production systems: yield potential, soil quality, and precision agriculture. Proc Natl Acad Sci U S A 96(11):5952-5959. doi:10.1073/pnas.96.11.5952

Chapagain T, Good A (2015) Yield and production gaps in rainfed wheat, barley, and canola in Alberta. Front Plant Sci 6:900. doi:10.3389/ fpls.2015.00990

Cunningham SA, Attwood SJ, Bawa KS, Benton TG, Broadhurst LM, Didham RK, McIntyre S, Perfecto I, Samways MJ, Tscharntke T, Vandermeer J, Villard M-A, Youg AG, Lindenmayer DB (2013) To close the yield-gap while saving biodiversity will require multiple locally relevant strategies. Agric Ecosyst Environ 173:20-27. doi: 10.1016/j.agee.2013.04.007

Denison RF, McGuire AM (2015) What should agriculture copy from natural ecosystems? Glob Food Secur 4:30-36. doi:10.1016/j.gfs. 2014.12.002

De Schutter O (2014) Report of the special rapporteur on the right to food. New York: United Nations General Assembly; 24 January 2014, 28 pp. http://www.srfood.org/images/stories/pdf/officialreports/ 20140310 final report en.pdf

De Wit CT (1992) Resource use efficiency in agriculture. Agric Syst 40: 125-151. doi:10.1016/0308-521X(92)90018-J

Doré T, Cadoret K, Makowski D, Malézieux E, Munier-Jolain N, Tchamitchian M, Tittonell T (2011) Facing up the paradigm of ecological intensification in agronomy : revising methods, concepts and knowledge. Eur J Agron 34:197-210. doi:10.1016/j.eja.2011.02.006

Duru M, Therond O, Fares M (2015) Designing agroecological transitions: a review. Agron Sustain Dev 35:1237-1257. doi:10.1007/ s13593-015-0318-x

FAO (2004) The ethics of sustainable agricultural intensification. Food and Agriculture Organization of the United Nations, Rome, ftp://ftp.fao.org/docrep/fao/007/j0902e/j0902e00.pdf; accessed 1 Dec 2016

FAO (2011a) The state of food insecurity in the world. How does international price volatility affect domestic economies and food security? Food and Agriculture Organization of the United Nations, Rome, http://www.fao.org/docrep/014/i2330e/i2330e.pdf; accessed 1 Dec 2016

FAO (2011b) Save and grow. A policymaker's guide to the sustainable intensification of smallholder crop production. FAO, Rome, 102 pp. http://www.fao.org/ag/save-and-grow/

Feenstra G (2002) Creating space for sustainable food systems: lessons from the field. Agr Hum Val 19(2):99-106. doi:10.1023/A: 1016095421310

Ferrer A, Celette F, Casagrande M, Peigné J, Vian JF, Wezel A (2017) Teaching agroecological practices to higher education students, farmers and other stakeholders. Examples from France. In: Wezel A (ed) Agroecological practices for sustainable agriculture: principles, applications, and making the transition. World Scientific Publishing Europe, London, UK,, pp 419-444

Firbank LG, Elliott J, Drake B, Cao Y, Gooday R (2013) Evidence of sustainable intensification among British farms. Agr Ecost Environ 173:58-65. doi:10.1016/j.agee.2013.04.010

Fischer J, Manning AD, Steffen W, Rose DB, Daniell K, Felton A, Garnett S, Gilna B, Heinsohn R, Lindenmayer DB, MacDonald B, Mills F, Newell B, Reid J, Robin L, Sherren K, Wade A (2007) Mind the sustainability gap. Trends Ecol Evol 22:621-624. doi:10.1016/j. tree.2007.08.016

Foley JJA, Ramankutty N, Brauman KA, Cassidy ES, Gerber JS, Johnston M, Mueller ND, O'Connell C, Ray DK, West PC, Balzer 
C, Bennett EM, Carpenter SR, Hill J, Monfreda C, Polasky S, Rockström J, Sheehan J, Siebert S, Tilman D, Zaks DPM (2011) Solutions for a cultivated planet. Nature 478(7369):337-342. doi: 10.1038/nature10452

Francis CA, Jensen ES, Lieblein BTA (2017a) Agroecologist education for sustainable development of farming and food systems. Agron J 109:23-32. doi:10.2134/agronj2016.05.0267

Francis C, Wiedenhoeft M, Dehaan R, Porter P (2017b) Education in agroecological learning: holistic context for learning farming and food systems. In: Wezel A (ed) Agroecological practices for sustainable agriculture: principles, applications, and making the transition. World Scientific Publishing Europe Ltd, London, UK,, pp 395-418

Fraser E, Legwegoh A, Krishna KC, CoDyre M, Dias G, Hazen S, Johnson R, Martin R, Ohberg L, Sethuratnam S, Senyd L, Smithers J, Van Acker R, Vansteenkiste J, Wittman H, Yada R (2016) Biotechnology or organic? Extensive or intensive? Global or local? A critical review of potential pathways to resolve the global food crisis. Trends Food Sci Tech 48:78-87. doi:10.1016/j.tifs.2015. 11.006

Garmestani AS, Benson MH (2013) A framework for resilience-based governance of social-ecological systems. Ecol Soc 18:9. doi:10. 5751/ES-05180-180109

Garnett T, Godfray HCJ (2012) Sustainable intensification in agriculture: navigating a course through competing food system priorities. Food Climate Research Network and the Oxford Martin Programme on the future of food. University of Oxford, Oxford

Garnett T, Appleby MC, Balmford A, Bateman IJ, Benton TG, Bloomer $\mathrm{P}$, Burlingame B, Dawkins M, Dolan L, Fraser D, Herero M, Hoffmann I, Smith P, Thornton PK, Toulmin C, Vermeulen SJ, Gadfray HCJ (2013) Sustainable intensification in agriculture: premises and policies. Science 341:33-34. doi:10.1126/science. 1234485

Garnier E, Navas ML (2012) A trait-based approach to comparative functional plant ecology: concepts, methods and applications for agroecology. Agron Sustain Dev 32:365-399. doi:10.1007/s13593-0110036-y

Ge L, Anten NPR, Van Dixhoorn IDE, Feindt PH, Kramer K, Leemans R, Meuwissen MPM, Spoolder H, Sukkel W (2016) Why we need resilience thinking to meet societal challenges in bio-based production systems. Curr Opin Env Sust 23:17-27. doi:10.1016/j.cosust. 2016.11.009

Geertsema W, Rossing WAH, Landis DA, Bianchi FJJA, Van Rijn PCJ, Schaminée JHJ, Tscharntke T, Van der Werf W (2016) Actionable knowledge for ecological intensification of agriculture. Front Ecol Environ 14(4):209-216. doi:10.1002/fee.1258

Gurr GM, Lu Z, Zheng X, Xu H, Zhu P, Chen G, Yao X, Cheng J, Zhu Z, Catindig JL, Villareal S, Chien HV, Cuong LQ, Channoo C, Chengwattana N, Lan LP, Hai LH, Chaiwong J, Nicol HI, Perovic DJ, Wratten SD, Heong KL (2016) Multi-country evidence that crop diversification promotes ecological intensification of agriculture. Nat Plants 2 (March 2016). Article number: 16014, doi: 10.1038/ nplants.2016.14

Holling CS (1996) Engineering resilience versus ecological resilience. In: Schulze PC (ed) Engineering within ecological constraints. The National Academic Press, Washington, D.C., USA, pp 31-44

IPES-Food (2016) From uniformity to diversity: a paradigm shift form industrial agriculture to diversified agroecological systems. International Panel on Sustainable Food Systems. Available at www.ipes-food.org; accessed 1 Dec 2016

Jackson L, Van Noordwijk M, Bengtsson J, Foster W, Lipper L, Pulleman M, Said M, Snaddon J, Vodouhe R (2010) Biodiversity and agricultural sustainagility: from assessment to adaptive management. Curr Opin Env Sust 2:80-87. doi:10.1016/j.cosust.2010.02.007

Keating BA, Carberry PS, Bindraban PS, Asseng S, Meinke H, Dixon J (2010) Eco-efficient agriculture: concepts, challenges and opportunities. Crop Sci 50:S109-S119. doi:10.2135/cropsci2009.10.0594
Kolb D (1984) Experiential learning. Experience as the source for learning and development. Prentice Hall, Englewood Cliffs

Kuyper TW, Struik PC (2014) Epilogue: global food security, rhetoric, and the sustainable intensification debate. Curr Opin Env Sust 8:7179. doi:10.1016/j.cosust.2014.09.004

Lammerts van Bueren E (2016) Enhancing resilience through plant breeding requires an integrated and interdisciplinary approach. In: Davis K (ed) Cultivating resilience. Proceedings of the 8th Organic Seed Growers Conference. February 4-6, 2016, Corvallis, OR. Organic Seed Alliance, Port Townsend, WA, pp 133-134

Levain A, Vertès F, Ruiz L, Delaby L, Gascuel-Odoux C, Barbier M (2015) 'I am an intensive guy': the possibility and conditions of reconciliation through the ecological intensification framework. Environ Manag 56:1184-1198. doi:10.1007/s00267-015-0548-3

Lieblein G, Breland TA, Francis C, Østergaard E (2012) Agroecology education : action-oriented learning and research. J Agric Educ Ext 18(1):27-40. doi:10.1080/1389224X.2012.638781

Loos J, Abson DJ, Chappell MJ, Hanspach J, Mikulcak F, Tichhit M, Ficher J (2014) Putting meaning back into "sustainable intensification". Front Ecol Environ 12(6):356-361. doi:10.1890/130157

Mahon N, Crute I, Simmons E, Islam MM (2017) Sustainable intensification - "oxymoron" or "third-way"? A systematic review. Ecol Indic 74:73-97. doi:10.1016/j.ecolind.2016.11.001

Martin AR, Isaac ME (2015) Plant functional traits in agroecosystems: a blueprint for research. J Appl Ecol 52:1425-1435. doi:10.1111/ 1365-2664.12526

Milder JC, Garbach K, DeClerck FAJ, Montenegro M, Driscoll L(2012) An assessment of multi-functionality of agroecological intensification. A report prepared for the Bill and Melinda Gates Foundation, September 2012. EcoAgriculture Partners, Ithaca, NY

Mueller ND, Gerber JS, Johnston M, Ray DK, Ramankutty N, Foley JA (2012) Closing yield gaps through nutrient and water management Nature 490:254-257. doi:10.1038/nature 11420

Petersen B, Snapp B (2015) What is sustainable intensification? Views from experts. Land Use Policy 46:1-10. doi:10.1016/j.landusepol. 2015.02 .002

Pretty JN (1997) The sustainable intensification of agriculture. Nat Resour Forum 21:247-256. doi:10.1111/j.1477-8947.1997. tb00699.x

Pretty JN (2008) Agricultural sustainability: concepts, principles and evidence. Philos T R Soc B 363(1491):447-465. doi:10.1098/rstb. 2007.2163

Pretty JN, Toulmin C, Williams S (2011) Sustainable intensification in African agriculture. Int J Agr Sustain 9(1):5-24. doi:10.3763/ijas. 2010.0583

Qin H (2010) Rural-to-urban labor migration, household livelihoods, and the rural environment in Chongqing Municipality, Southwest China. Hum Ecol 38:675-690. doi:10.1007/s10745-010-9353-z

Raworth K (2017) Doughnut economics. Seven ways to think like a 21stcentury economist. Cornerstone, New Orleans

Rittel HWJ, Webber MM (1973) Dilemmas in a general theory of planning. Policy Sci 4(2):155-169. doi:10.1007/BF01405730

Robertson GP, Vitousek PM (2009) Nitrogen in agriculture: balancing the cost of an essential resource. Annu Rev Environ Resour 34:97-125. doi:10.1146/annurev.environ.032108.105046

Rockström J, Steffen W, Noone K, Persson A, Chapin III FS, Lambin E, Lenton TM, Scheffer M, Folke C, Schellnhuber H, Nykvist B, De Wit CA, Hughes T, Van der Leeuw S, Rodhe H, Sörlin S, Snyder PK, Costanza R, Svedin U, Falkenmark M, Karlberg L, Corell RW, Fabry VJ, Hansen J, Walker B, Liverman D, Richardson K, Crutzen P, Foley J (2009) Planetary boundaries: exploring the safe operating space for humanity. Ecol Soc 14(2): 32. [online] URL:http://www. ecologyandsociety.org/vol14/iss2/art32/

Ruben R, Lee DR (2000) Combining internal and external inputs for sustainable intensification. Policy document no. 65. International Food Policy Research Institute (IFPRI), Washington, USA 
Sadras VO, Denison R (2016) Neither crop genetics nor crop management can be optimised. Field Crops Res 189:75-83. doi:10.1016/j/ fc. 2016.01 .015

Satterthwaite D, McGranahan G, Tacoli C (2010) Urbanization and its implications for food and farming. Philos T R Soc B 365:2809 2820. doi:10.1098/rstb.2010.0136

Smith A, Snapp S, Chikowo R, Thorne P, Bekunda M, Glover J (2017) Measuring sustainable intensification in smallholder agroecosystems: a review. Glob Food Secur 12:127-138. doi:10. 1016/j.gfs.2016.11.002

Spiertz H (2010) Food production, crops and sustainability: restoring confidence in science and technology. Curr Opin Env Sust 2:438443. doi:10.1016/j.cosust.2010.10.006

Spiertz H (2012) Avenues to meet food security. The role of agronomy on solving complexity in food production and use. Eur J Agron 43:1-8. doi:10.1016/j.eja.2012.04.004

Steffen W, Richardson K, Rockström J, Cornell SE, Fetzer I, Bennett EM, Biggs R, Carpenter SR, De Vries W, De Wit CA, Folke C, Gerten D, Heinke J, Mace GM, Persson LM, Ramanathan V, Reyers B, Sörlin S (2015) Planetary boundaries: guiding human development on a changing planet. Science 347:1259855. doi:10.1126/science. 1259855

Sterling S (2009) The ecological and environmental dimensions of the holistic curriculum. In: Farrell RV, Papagiannis G (eds) Education for sustainability. Encyclopedia of life support systems. Eolss Publishers, Oxford, UK, pp 309-322

Struik PC, Kuyper TW, Brussaard L, Leeuwis C (2014) Deconstructing and unpacking scientific controversies in intensification and sustainability: why the tensions in concepts and values? Curr Opin Env Sust 8:80-88. doi:10.1016/j.cosust.2014.10.002

Sumberg J, Andersson J, Giller K, Thompson J (2013a) Commentary: Response to 'Combining sustainable agricultural production with economics and environmental benefits'. Geogr J 179(2):183-185. doi:10.1111/j.1474-4954.2012.00472x

Sumberg J, Thompson J, Woodhouse P (2013b) Why agronomy in the developing world has become contentious. Agr Hum Val 30:71-83. doi:10.1007/s10460-012-9376-8

Thwink.org (2014) Finding and resolving the root causes of the sustainability problem http://www.thwink.org/sustain/glossary/ Sustainability.htm. Accessed 12 June 2017

Tittonell P (2014) Ecological intensification of agriculture-sustainable by nature. Curr Opin Env Sust 8:53-61. doi:10.1016/j.cosust.2014. 08.006

Tittonell P, Giller KE (2013) When yield gaps are poverty tramps: the paradigm of ecological intensification in African smallholder agriculture. Field Crops Res 143:76-90. doi:10.1016/j.fcr.2012.10.007

Trawick P, Hornborg A (2015) Revisiting the image of limited good: on sustainability, thermodynamics, and the illusion of creating wealth. Curr Anthropol 56(1):1-27. doi:10.1086/679593
Uphoff N (2014) Systems thinking on intensification and sustainability: systems boundaries, processes and dimensions. Curr Opin Env Sust 8:89-100. doi:10.1016/j.cosust.2014.10.010

Urruty N, Tailliez-Lefebvre D, Huyghe C (2016) Stability, robustness, vulnerability and resilience of agricultural systems. A review. Agron Sustain Dev 36:1-15. doi:10.1007/s13593-015-0347-5

Valenzuela H (2016) Agroecology: a global paradigm to challenge mainstream industrial agriculture. Horticulturae 2(2):2. doi:10.3390/ horticulturae2010002

Van Bueren EM, Lammerts van Bueren ET, Van der Zijpp AJ (2014) Understanding wicked problems and organized irresponsibility: challenges for governing the sustainable intensification of chicken meat production. Curr Opin Env Sust 8:1-14. doi:10.1016/j.cosust. 2014.06.002

Van Ittersum MK, Cassman KG, Grassini P, Wolf J, Tittonell P, Hochman Z (2013) Yield gap analysis with local to global relevance - a review. Field Crops Res 143:4-17. doi:10.1016/j.fcr.2012.09.009

Vanloqueren G, Baret PV (2009) How agricultural research systems shape a technological regime that develops genetic engineering but locks out agroecological innovations. Res Policy 38:971-983. doi: 10.1016/j.respol.2009.02.008

Van Noordwijk M (2017). Blog with reflections on "Efficiency in the agriculture of the $21^{\text {st }}$ century". Meeting organised by de Wetenschappelijke Raad voor Integrale Duurzame Landbouw en Voeding, Ede, 9 June 2017

Van Noordwijk M, Brussaard L (2014) Minimizing the ecological footprint of food: closing yield and efficiency gaps simultaneously? Curr Opin En Sust 8:62-70. doi:10.1016/j.cosust.2014.08.008

Walker J, Cooper M (2011) Genealogies of resilience: from systems ecology to the political economy of crisis adaptation. Secur Dialogue 42: 143-160. doi:10.1177/0967010611399616

Wals AEJ (2015) Beyond unreasonable doubt. Education and learning for socio-ecological sustainability in the anthropocene. Inaugural address, Wageningen University, Wageningen, 17 December 2015, 36 pp. ISBN 978-94-6257-369-7

WCED (World Commission on Environment and Development) (1987) Our common future. Oxford University Press, Oxford

Weekley J, Gabbard J, Nowak J (2012) Micro-level management of agricultural inputs: emerging approaches. Agronomy 2012(2):321357. doi:10.3390/agronomy 2040321

Wezel A, Soboska G, McClelland S, Delespesse F, Boissau A (2015) The blurred boundaries of ecological, sustainable, and agroecological intensification: a review. Agron Sustain Dev 35:1283-1295. doi: 10.1007/s13593-015-0333-y

Wynne B (2010) When doubt becomes a weapon. Nature 466:441-442. doi:10.1038/466441a

Zhang X, Davidson EA, Mauzerall DL, Searchinger TD, Dumas P, Shen Y (2015) Managing nitrogen for sustainable development. Nature 528:51-59. doi:10.1038/nature15743 